UNITED STATES DEPARTMENT OF THE INTERIOR GEOLOGICAL SURVEY

A PROVISIONAL RADIOLARIA BIOSTRATIGRAPHY, LATE DEVONIAN THROUGH LATE PERMIAN

By

Brian K. Holdsworth and David L. Jones

Open-file Report

80-876

This report is preliminary and has not been edited or reviewed for conformity with Geological Survey standards or nomenclature 
A PROVISIONAL RADIOLARIA BIOSTRATIGRAPHY,

\section{LATE DEVONIAN THROUGH LATE PERMIAN}

by

Brian K. Holdsworth and David L. Jones

\section{INTRODUCTION}

This report provides a preliminary outline of a scheme for dating Late Devonian through Late Permian rock samples that contain reasonably well-preserved radiolarian faunas. The scheme is of most value in providing relative ages of samples from bedded chert terranes where few or no other means of age estimation are available. Provisional estimates of relative age are provided for a number of chert samples collected by U.S. Geological Survey and other field workers from Cordilleran formations (column A of chart).

Such dating is achieved by allocating a chert fauna to one of nine major, time-successive assemblages herein defined (column $D$ of chart). The position and range of each assemblage in terms of standard stages or series is estimated (column $F$ of chart). The earlier six assemblages appear to belong to Frasnian through 0sagean; the latter three range from probable Chesterian through Guadalupian. The natures of Meramecian, and Ochoan through Spathian, Radiolaria associations are still uncertain, but faunal changes which are inferred to have occurred during Meramec deposition and prior to or during deposition of the Ochoan and Anisian are shown (column $C$ of chart). Samples believed to be of such ages are indicated (columns $A$ and $E$ of chart). 
The scheme is provisional and considerable uncertainties remain regarding the precise geologic time ranges of individual assemblages. Each assemblage contains the product of a single, index faunal-change "event" (columns B and C of chart; see below). However, in some cases, column $C$ of chart indicates that several events appear to have been coincident with that which gave rise to the assemblage index taxon. In part this "clustering" of events almost certainly reflects an explosive rate of change of radiolarian faunas during latest Devonian and earliest Mississippian time. But elsewhere in the column clustering of events may reflect no more than the present inadequate sampling of the total time-rock record.

\section{PRESENTATION \\ (1). The Events Chart (Column C)}

The basic data regarding the apparent nature and relative ages of individual faunal events in Frasnian through Anisian radiolarian populations is summarized in column $C$ of chart. This data derives in part from studies of Paleozoic Radiolaria prior to 1976 (see Holdsworth, 1977, for summary), in part from a few important studies published subsequent to the preparation of Holdsworth (1977) and in very large part from unpublished studies of faunas separated from North American cherts by the HF washing technique (Pessagno and Newport, 1971; Holdsworth and others, 1978) since 1976. 
The conventions used in presenting this body of data in the form of an "events chart" are very similar to those now routinely used in presenting summaries of data on Mesozoic and Cenozoic faunas. It is stressed, however, that the quality of data is much poorer for Paleozoic events than for younger events. The "morphotypic base" or first appearance of a distinctive morphotype or morphotype group of unknown evolutionary origin is indicated by "m.b". The last (top) appearance of any morphotype or morphotype group is indicated by "m.t". Where grounds exist for believing that a particular morphotype or morphotype group originated by evolutionary change in an identifiable "ancestor" morphotype or morphotype group, ancestor(s) and descendant(s) are indicated "... ...". (In the present chart the arrow symbol does not imply critical change in frequency of ancestor and descendant as it has been used in some cases by previous authors.)

Evolutionary events of this last type are of the greatest biostratigraphic significance, for if correctly identified they must be timesuccessive and the evidence of their occurrence is likely to be relatively little perturbed by paleoecologic factors. A potential strength of the scheme set out in the chart is that eight of the nine biostratigraphic assemblages are defined in terms of index events of this type. 
(2). Assignment of assemblages to stage/series (column F) and reference faunas (columns $E, G$ )

The greatest difficulty attends the independent geologic dating of successive segments of the Late Devonian through Permian Radiolaria record. Radiolarian rocks of this time span of ten contain few other fossil groups and frequently none of biostratigraphic utility. Conodonts, infrequently found in chert residues, provide the mainstay of our calibration. Conodonts are, however, prone to lengthy reworking in all environments and apparently are subject sometimes to morphologic modification in the deeper water bedded chert environment. Key reference faunas with conodonts (or other biostratigraphically significant content or context) which are relied upon for calibration of assemblages with the Geologic Rock-Time and Time scales are indicated by unbracketed numbers in column $E$ of chart and European Carboniferous samples in column G.

Some radiolarian datum levels dated only by coexisting conodonts may in some cases have been assigned too great an age. For two samples, ages based on conodonts were rejected as there appeared great conflict between present understanding of the Radiolaria succession and the apparent "conodont age." In these cases reworking is postulated. $B$ racketed numbers in columns $E$ and $F$ indicate these samples and others of questionable value for calibration purposes. 


\section{(3). Paleontology}

Advances in biostratigraphic understanding of the later Paleozoic Radiolaria has far outstripped publication of new data since 1977. Nevertheless, the great majority of taxa utilized in the scheme are named species, genera and families which will be familiar to the specialist. Important new, unpublished taxa are indicated "..." in column $C$ of chart and briefly described in Notes on Paleontology and Evolution (below). Where Paleozoic species are thought to be allotted to inappropriate genera, but for which new names have not yet been proposed, the currently used genus is indicated '....'.

THE EVENTS CHART AND ASSEMBLAGES

Below are provided definitions and brief discussions of assemblages and Radiolaria associations not yet allotted an assemblage. Critical reference faunas used or rejected in age assignment of assemblages are detailed, the numbers allocated to faunas in the text being those used in columns $E$ and $G$ of chart. Roman numerals in the text refer to notes in the paleontology-evolution section.

Note that the earliest group of four events shown in the chart are only known to postdate the Wenlockian and predate the base of the Frasnian. 
(A). Pre-Holoeciscus Assemblage, Late Devonian part

Distinguishable from Holoeciscus-1 Assemblage by absence of Holoeciscus Foreman in ceratoikisciid populations and by absence of Cyrtentactinia Foreman and all Pylentonemidae.

1, 2: Faunas with lower Polygnathus asymmetricus Zone conodonts cited in Holdsworth (1977). 3: Fauna from Frasnian portion of Egindinskaya Series, Urals (Nazarov, 1975).

Faunas of Assemblage with many entactiniid spumellarian species groups also known from Holoeciscus-1 Assemblage (cf. Foreman, 1963). Ceratoikisciid population also dominated by species groups common to Holoeciscus-1--Ceratoikiscum spinosiarcuatum Foreman Group (i), Ceratoikiscum bujugum Foreman Group (ii), and Ceratoikiscum planestellare Foreman Group.

No basal datum event is yet available to demark the Frasnian faunas of this assemblage from faunas of pre-Frasnian, Devonian age. Faunas of Wenlockian age are, however, clearly distinct from the Frasnian faunas cited here (see Holdsworth, 1977).

(B). Holoeciscus-1 Assemblage

The concept of this assemblage derives from 4: faunas described by Foreman (1963) from the lower portion of the Ohio Shale, apparently of earliest Famennian, upper Palmatolepis crepida Zone age (Winder, 1966). Faunas of assemblage postdate the index event of the evolution of the earliest known Holoeciscus - Holoeciscus auceps Foreman - from an unknown ceratoikisciid, probably Ceratoikiscum ancestor (iii). They predate the first appearance of Holoeciscus sp. nov. (iv) and the possible extinction of $\underline{H}$. auceps, and also the first appearance of Popofskyellum Deflandre, viewed as the evolutionary descendant of the monospecific Cyrtentactinia Foreman s.s. (v). 
(C). Holoeciscus-2 Assemblage

Type faunas of Assemblage are from upper basalt-free red cherts of Chulitna ophiolite, Alaska Range (Jones and others, in press). These faunas postdate the index first appearance of Holoeciscus sp. nov. (iv), the apparent extinction of $\underline{H}$. auceps and the transition Cyrtentactinia -- Popofskyel lum (v). Archocyrtium Deflandre, first known in the Wenlockian, makes a reappearance after apparent absence from the Frasnian pre-Holoeciscus and Holoeciscus-1 as semblages. Assemblage is distinguished from Holoeciscus -3 assemblage by absence of Pylentonema Deflandre and much greater abundance of Holoeciscus.

No fauna of assemblage is reliably dated by independent means, but the type faunas are of critical importance. Their excellent preservation and apparently truly oceanic provenance allows a reliable glimpse to be obtained of generic diversity achieved during the peak period of Holoeciscus abundance. 
(D). Holoeciscus-3 Assemblage

Type fauna - 5 - is fron Woodruff Formation (R. K. Hose, collector) some one-third of a mile northwest from localities 42 and 43 of Smith and Ketner (1975) which yielded Platyclymenia. Occurrence of the goniatites suggests but does not convincingly prove that 5 is of midFamennian age. Recent redating of the Webb Formation as 0sagean ( $R$. K. Hose, written commun., 1979) raises the possibilities of Kinderhookian levels within the Woodruff.

Assemblage distinguished from Holoeciscus-2 by presence of Pylentonema sp. nov. 1 ( vi) with inner lattice, very probably derived from Formaniella cibdelosphaera (Foreman) or a derivative therefrom (vi-vii). Faunas of assemblage distinguished from those of Albaillella-l Assemblage by absence of all albaillellids and all septactine Pylentonemidae other than Pylentonema. 


\section{(E). Albaillella-l Assemblage}

Index event is the first appearance of the primitive Albaillella sp. nov. (viii), which appears to be the evolutionary derivative of Holoeciscus (ix). The latter genus is not definitely known from any fauna of the assemblage. Apparently simultaneous with the first known appearance of Albaillella are the cryptophyletic first appearances of the septactine pylentonemids Cyrtisphaeractenium Deflandre, Cyrtisphaeronemium Deflandre, and Pararchocyrtium Deflandre - all genera of the remarkably rich pylentonemid faunas previously recognized in the early Carboniferous of France and Turkey (see Holdsworth, 1977, for discussion) being now present. Faunas of the assemblage are distinguished from those of the Albaillella-2 Assemblage by the absence of Albaillella paradoxa Deflandre Group (xiii). The distinctive Ceratoikiscum avimexpectans Deflandre $(x)$ first appears in this Assemblage.

Type fauna is from allochthonous, Woodruff-like cherty siltstone of Fish Creek Range, Nevada (R. K. Hose locality 79-30). This locality is not independently dated. Poorly preserved faunas (6) of the "Lower" Ford Lake Shale, Alaska, at Alaska Museum locality A854 (see Holdsworth and others, 1978) contain the distinctive spiral-spine spheroids $(x i)$ of Albaillella-l and occur within 30 feet of an overlying Albaillella-2 level and 6 feet below the first known level with the lowest Kinderhookian conodont Siphonodella sulcata.

The Albaillella-1 Assemblage thus appears to be immediately preKinderhookian and/or basal Kinderhookian (but see below). 
(F). Albaillella-2 Assemblage

Faunas of Assemblage postdate the index first appearance of $\underline{A}$. paradoxa Group (xiii), very probably the descendant of Albaillella sp. nov. (xii). Type fauna - 10 - from phosphatic nodule, Baltalimani Formation, Turkey (Holdsworth, 1973) also contains Albaillella undulata Deflandre and Albaillella cornuta Deflandre.

10: Underlies limestone level with latest Tournaisian Foraminifera; 11: Cabrieres district, Montagne Noire, France; lydite unit with early Visean goniatites; 8: Fish Creek Range, Nevada, R. K. Hose locality 78-115; cherty shale in probable mid-0sagean shale-limestone unit; 9: Fish Creek Range, R. K. Hose localities 78-40 and 78-75; cherty shale ca $300 \mathrm{ft}$ above limestones with mid-0sagean algae and Foraminifera.

(7): Ford Lake Shale, Alaska Museum locality A854; chert levels under- and overlain by basal Kinderhookian conodonts of Siphonodella sulcata and Siphonodella sandbergi-Siphonodella duplicata Zones. Faunas of (7) appear to indicate that this assemblage existed at least from earliest Kinderhookian, but Late Devonian conodonts are reworked in the section and so may be the Kinderhook elements. If so, Albaillella1 may well be Kinderhookian and Albaillella-2 entirely post-Kinderhookian. 
(G). Uncertain-Radiolaria associations of apparent Meramecian

age

Presently, all faunas with $\underline{A}$. paradoxa Group are considered to belong to the Albaillella-2 assemblage. The well-known association of A. paradoxa with Cyrtisphaeractenium is firmly dated in Europe as being at least as young as basal Visean - 11 - and in America at least as young as mid-0 sagean - 8,9 .

At locality A854 in the Ford Lake Shale of Alaska, the extinction levels of both Cyrtisphaeractenium and Cyrtisphaeronemium apparently lie below level C.8 in the "Lower" Ford Lake Shale, and occur within the range of A. paradoxa Group. C.8 contains the earliest Pylentonema sp. nov. $2(x v)$ and Pylentonemid gen nov. (xvi). Independently undated samples with $\underline{A}$. paradoxa Group but lacking Cyrtisphaeractenium and Cyrtisphaeronemium are also known from the Tobin Range and Edna Mountains, Nevada (column A of chart), and it appears that these "late" Albaillella2 faunas are at least as young as late 0sagean and very probably of Meramecian age.

Independently undated faunas from Brooks Range, Alaska, lack $\underline{A}$. paradoxa Group but contain A. undulata Group (xiv) in association with lanceolate, well-segmented Albaillella spp. of "advanced" type (xviii). One fauna - (12) - of this association type, Cache Creek Group, British Columbia (Whetten 77-5E), contained a conodont as semblage of apparent late Kinderhookian age. The nature of the Radiolaria assemblage is so different, however, from faunas of Early Mississippian age dated by Foraminifera and ammonoids (see above) that the apparent date is rejected in this synthesis. 
The Sycamore Limestone, Oklahoma - (13) - lacks all Pylentonemidae, all early tubular Albaillellas including $\underline{A}$. paradoxa and $\underline{A}$. undulata Groups and contains the apparently "advanced" Albaillella cartalla Ormiston and Lane (Ormiston and Lane, 1976). Several other features of this Radiolaria fauna also suggest a level younger than that of earliest 0sagean which is indicated by co-existing conodonts. The radiolarian beds of the lower Sycamore are here considered to be of later Meramecian age, probably not significantly older than the "latest Meramec or early Chester" conodonts reported as occurring some $182 \mathrm{ft}$ above the base of the formation (Ormiston and Lane, 1976, p. 164).

(H). Albaillella-3 Assemblage

Index event is first appearance of Albaillella pennata Holdsworth Group ( $x$ xii), possibly derived from poorly known supposedly Meramecian lanceolate or winged segmented forms, possibly from A. cartalla. Faunas of assemblage predate the evolutionary first appearance of "Pseudoalbaillella spp." (xxiv). Type collection is from Reticuloceras circumplicatile s.s. goniatite band, Dove Shale, Derbyshire, England (Holdsworth, 1966).

14: Concretion with latest Visean, (Zone P2b), goniatites, County Clare, Ireland; 15: Concretion, Hombergian (EI), Fayetteville Shale, Arkansas (Nigrini and Nitecki, 1968); 16-18: Concretions with E2-R1 goniatites, Dove and Edale Shales, Derbyshire, England; (19): Concretion from basal R2, Reticuloceras gracile goniatite band, North Staffordshire, England. The Radiolaria fauna is poorly diversified and does not convincingly prove the absence of "Pseudoalbaillella". 
18A: Cherts, Mystic area, Alaska, which contain Albaillella pennata s.s. and are thus unlikely to predate Namurian H2-Rl. Lack Spongodiscaceid gen. nov. (tetrahedral) (xxiii) though containing Spongotripus ( $x i x$ ). The morphotypic base of Spongodiscaceid gen. nov. (tetrahedral) appears, therefore, to be post at least $\mathrm{H} 2$.

The P2b Irish concretions (14) contain the youngest examples of 'Ceratoikiscum' omicron Ormiston and Lane Group ( $x x)$ and the earliest "Parahagiastriids" (xxi). Paronaella impella Group (xvii), 'Spongotripus' and Spongodiscaceid gen. nov. (tetrahedral) ( $x x i i i)$ are all to be expected in faunas of this assemblage. They are known, however, only from bedded chert faunas, occurring neither in the black shale goniatite bands of England and Ireland, cited above, or in the single Fayetteville fauna. These forms appear to have been excluded from the relatively shallow, enclosed, black shale seas. Independently undated faunas from the Toyabe Range, Nevada, and Mystic area of Alaska, in at least one case with Albaillella pennata s.s., contain the youngest known Pylentonemidae, including Pylentonemid gen. nov. As previously suggested (Holdsworth, 1973, 1977) it appears that this group also was excluded by environmental factors from the Namurian black shale environments and also apparently from the intracontinent environment of the Sycamore Limestone, Arbuckle Mountains, Oklahoma (see above). 


\section{(I). "Pseudoalbaillella" Assemblage}

Index event is the first appearance of "Pseudoalbaillella" spp. (xxiv), most probably the evolutionary derivatives of $\underline{A}$. pennata Group and quite possibly of Albaillella pennata s.s. or its direct Albaillella descendant $(x x v)$. Complex Paronaella s.1. spp. (xxvi) first appears in the Assemblage and "Parafollicucullus" spp. (xxviii) and mammilate spheroids $(x x x)$ first appear in Leonardian faunas of Assemblage.

20: Chert of Kagvik sequence, Brooks Range, Alaska; Mayfield collection 78Md-75E. This sample has a "Pseudoalbaillella" population gradational with $\underline{A}$. pennata and contains a conodont of the Idiognathoides noduliferous Group. This conodont group ranges in Britain from Namurian, H2 to Namurian, G1 (early to early-late Morrowan). As "Pseudoalbaillella" is absent in Britain at least to early Kinderscoutian, RI (see above) 78Md-75E can be no older than Marsdenian, R2, or younger than Yeadonian, G1 - presuming no conodont reworking. (21): Cherts of Havallah Sequence, Nevada, with "Pseudoalbaillella"; both samples lack 'Spongotripus' and Spongodiscaceid gen. nov. (tetrahedral) and must postdate the extinctions of these forms: $77-\mathrm{J}-16$ with Idiognathoides macer could be at least as young as G2, latest Morrowan, but 77-J-24 with Idiognathoides noduliferous Group can apparently be no younger than G1. This suggests a very short range indeed - $42-G 1$ at most - for the tetrahedral spongodiscaceid. So short a range seems inherently improbable in view of the relatively large number of samples known to contain this form. Pending confirmation, therefore, m.t. Spongodiscaceid gen. nov. (tetrahedral) is considered to be of unknown position within the mid-Late Pennsylvanian, predating the first appearance of "Pseudoalbaillella U-forma" (xxvii). 
The "Pseudoalbaillella" transition may, in fact, be post-Morrowan. 22: Concretions with Eoasianites (Glaphyrites) rionegrens is Closs, Uruguay, of supposed but not certain Middle Pennsylvanian age appear to lack "Pseudoalbaillella" in their Albaillella populations. This suggests that the first appearance of "Pseudoalbaillella" should be taken to postdate some part of the Middle Pennsylvanian but predate 23: late Desmoinesian concretions with "Pseudoalbaillella", Kansas (Nodine-Zeller, Holdsworth, and Berenson, in press).

Early Permian faunas of this assemblage appear distinctive and are relatively convincingly dated. 24: Chert, Alaska, 77AFr-3189; 25: Chert, Washington State, 77-55B; 26: Chert block in melange with Leonardian conodonts, Cache Creek, B.C.; 27: Chert, 77-J-19, Havallah Sequence, Nevada, with probable Leonardian Neogondolella. 
(J). Follicucullus Assemblage

Index event is the first appearance of Follicucullus Babstock and Ormiston, apparently the evolutionary derivative of an unrecognized but probably generalized form of "Pseudoalbaillella" (xxix, but see also xxviii). Type fauna is 29: Lamar Limestone, Texas, Late Guadalupian (Ormiston and Babstock, 1979).

28: Chert, Klamath Mountains, Irwin-22-77, with Wordian conodonts.

(K). Uncertain associations of post-Guadalupian and possibly post-Guadalupian age

(30): Poor fauna from chert, overlying Leonardian Limestone and underlying Triassic sandstone; 78-JSE-3. Contains no familiar elements of "Pseudoalbaillella" or Follicucullus Assemblages and no recognizable Triassic elements. Contains "Helioasters" ( $x x x i)$, presently unique to this sample. 31: Chert, 78Md-293. Contains conodonts of SpathianAnisian age. Radiolaria assemblage poorly preserved and of low diversity, with simple multicyrtoids ( $x x x i i$ ) of Mesozoic type, lacking many characteristic forms of the Late Triassic. 
Notes on Paleontology and evolution

by

$$
\text { Brian K. Holdsworth }
$$

Notes on new taxa and evolutionary events are numbered in order of appearance from base of events chart.

(i) Ceratoikiscum spinosiarcuatum Group: Ceratoikiscum spinosiarcuatum Foreman s.s. provides the type for a rather variable group of morphotypes in which three to five caveal ribs, of ten more elaborately vaned than in the type form, are confined to a.t., the posteriormost rib pair $\left(C_{l}\right)$ distally joining the frame. In $\underline{C}$. spinosiarcuatum s.s. rejunction is with b.v., but the early Frasnian Canol Shale fauna contains morphotypes possessing b.v. but having $C_{1}$ rejunction either with the posterio-ventral patagium or with a new, discrete rod--"focus rod"--developed from the patagium. This rod is clearly the so-called "offset b.v." of Ceratoikiscum tricancellatum Holdsworth of the Albaillella-3 Assemblage and demonstrates the close phyletic connection between these Ceratoikiscum spp. of widely different age. The extreme scarcity of the $\underline{C}$. Spinosiarcuatum Group in good Albaillella1 and -2 faunas is thus puzzling.

(ii) Ceratoikiscum bujugum Group: The form in the Pre-Holoeciscus, Canol Shale fauna, seems to differ from the Holoeciscus-1 type in possessing a second, posterior pair of delicate ribs. 
(iii) Holoeciscus appears to have arisen from a Ceratoikiscum with caveal ribs developed on both a.t. and the dorsal half of b.t. Change involved an equal degree of lengthening of b.t. and i.t. relative to a.t., and the development of lamellar shell between caveal ribs (Foreman, 1963; Holdsworth, 1969).

(iv) Holoeciscus sp. nov. Differs from $\underline{H}$. auceps in possessing spinose instead of spongy $\mathrm{H}$-frame and having dorsal-most caveal rib pair of b.t. developed beyond shell periphery as upwardly curving spines.

(v) The appearance of simple, unsegmented Popofskyellum spp. apparently immediately succeeding the extinction of Cyrtentactinia tends to support the earlier inference of evolutionary relationship (see Holdsworth, 1973).

(vi) Pylentonema sp. nov. 1. A smaller form than Pylentonema antiqua Deflandre, with relatively longer spines and strong inner lattice. 
(vii) As far as can be determined Pylentonema sp. nov. 1 lacks the pylome net of Formaniella cibdelosphaera and may well have originated from this species by loss of net and acquisition of inner lattice. The very close relationship between Formaniella cibdelosphaera and Pylentonema spp. is demonstrated by the very rare Formaniella helenae Deflandre of a French Albaillella-2 fauna, a species which combines the pylome net of Formaniella with the internal lattice frequent in Pylentonema spp.

(viii) Albaillella sp. nov. Distinguished from all named Albaillellas by small, rather triangular unsegmented shell with single strong, spinose projections from both dorsal and ventral sides; $H$-frame spongy with well-developed external ribs dorsally. 
(ix) Albaillella sp. nov. apparently arose from an unrecognized Holoeciscus sp. in which the triangle-forming portion of the intersector rod (i.t.) lengthened dorsally. The perpendicular contact of a.t. with $i$ was thus changed to an oblique contact, giving a triangular rather than quadrangular shell in which b.t. and a.t. remain discernible as discrete arcs. The fundamental b.t./a.t. contact is marked by the dorsal spine of Albaillella sp. nov., the homologue of the Holoeciscus a.t./i.t. contact being marked by the ventral spine. The transformation is thus similar to that which gave rise to Lapidopiscum Deflandre, except that in this case the ancestor was a Ceratoikiscum (probably of Ceratoikiscum spinosiarcuatum Foreman Group) in which there had been no prior relative lengthening of b.t. as in Holoeciscus and in which caveal ribs had been lost from b.t. (see also Holdsworth, 1966).

(x) Ceratoikiscum avimexpectans Group. Inter-fauna variation in strength of extratriangular spines and tightness of packing of the numerous caveal ribs is evident. The very probable ancestor of this species group is known in the pre-Holoeciscus Canol Shale fauna, but Holoeciscus-1 through 3 examples are unknown. 
(xi) Spiral-spine spheroids. Probable latticed entactiniids usually with 6 but sometimes 4 remarkably bladed, corkscrew spines superficially similar to those of Triassic genera.

(xii) A. paradoxa retains the totally unsegmented shell of Albaillella sp. nov., the parallel rods of $\mathrm{H}$-frame, and strong external ribs. Spongy tissue of $\mathrm{H}$-frame and shell spines are lost and the original point of a.t./b.t. junction loses identity by smoothing of a.t. and b.t. into single curved rod.

(xiii) Albaillella paradoxa Group. Used for all forms with the slender, sword-sheath form of shell of A. paradoxa s.s. Probable earliest forms are thinner shelled and more delicate and inferred latest forms smaller than type.

(xiv) Albaillella undulata Group. Used for all narrowly conical, unwinged forms with multiple undulose segmentation. Inferred late examples are small.

(xv) Pylentonema sp. nov. 2. Larger and with consistently relatively shorter spines than $\underline{P}$. antiqua s.s.; probably the descendant of this form.

(xvi) Pylentonemid gen. nov. Shell essentially spherical, pores pustulate, podome at junction with lattice markedly constricted and podome skirt strongly flared with needlelike terminations of the three feet. Four other main spines weakly developed from lattice. At least one group of small forms in late Albaillella-2 and immediately younger faunas may well derive from Pylentonemid gen. nov. 
(xvii) Paronaella impella Group. Used for all simple Paronaella s.1. morphotypes with parallel-sided arms or arms of elongate club form.

(xviii) All present evidence suggests that the flattened rather than tubular shell-form in Albaillella, with marked oblique shell segmentation, is a relatively late acquisition and not inherited from the Albaillella ancestor.

(xix) 'Spongotripus'. Used for forms comparable with 'Spongotripus' ruestae Ormiston and Lane.

(xx) 'Ceratoikiscum' omicron Ormiston and Lane Group. Used for ceratoikiscids with single strong rib pair and modification of fundamental triangle to a ring. If omicron possesses, as is likely, the structure of undescribed latest Visean species it cannot usefully be included in Ceratoikiscum.

(xxi) "Parahagiastriids". A diverse, undescribed group, in which three or more usually very narrow arms (rays) originate from a small perforate or imperforate central sphere, the arms being usually constructed of longitudinal straight or serpentine rods linked by numerous cross struts. In the distinctive "trumpet form" of late Pseudoalbaillella assemblage faunas the arms expand rapidly into an abruptly truncated cone. 
(xxii) Albaillella pennata Group. Populations in different faunas show variation in strength and spinosity of $\mathrm{H}$-frame and development of wings. In type Rla(i) form, also present in $\mathrm{H} 2 \mathrm{a}$, the H-frame is extremely weak.

(xxiii) "Spongodiscaceid gen. nov. (tetrahedral)". Solid, large, spongy lattice produced into four solid, spongy conical, spine-terminated arms, each with central thread. Probably closely related to $\underline{P}$. impella Group and 'Spongotripus'.

(xxiv) "Pseudoalbaillella". Conical to bilaterally flattened, winged, imperforate shells of unknown internal structure, sometimes superficially similar to late forms of Albaillella, but distinguished therefrom by pronounced, median, swollen "pseudothorax" bearing wings in plane of bilateral symmetry. Apical cone and "pseudoabdomen" often with subsidiary external segmentation. Differs from Follicucullus Ormiston and Lane in possession of winged pseudothorax. 
(xxv) Though it is not known whether "Pseudoalbaillella" ever possessed an external $\mathrm{H}$-frame, early forms show a remarkable similarity in shell form to the late Albaillella pennata which provides a wholly logical ancestor. The locus of pseudothorax development is apparently a girdle which contains the original sites of the a.t./b.t. and a.t./i.t. junctions in the Holoeciscus ancestor of Albaillella (see vii, above). It is unlikely that "Pseudoalbaillella" possessed an $\mathrm{H}$-frame, for in $\underline{A}$. pennata Group reduction in strength of this structure proceeded rapidly in Namurian time and it is extremely weak in $\underline{A}$. pennata s.s. of the Kinderscoutian (RI).

(xxvi) "Complex Paronaella s.1. spp." Three armed forms with triangular or abruptly clubbed terminations to arms, the terminations frequently joined one with the other.

(xxvii) "Pseudoalbaillella U-forma". Pseudoalbaillella with narrowly tapering shell, totally lacking secondary segmentation, strongly constricted below very small, subspherical pseudothorax and with rapidly flaring distal pseudoabdomen strongly reflexed to form tight $U$-bend with proximal portion. 
(xxviii) "Parafollicucullus". Distinguished from "Pseudoalbaillella" by additional, ringlike, inflated major segment interposed in constriction between "pseudothorax" and "pseudoabdomen." Murchey (oral commun., 1979) notes the possibility of phyletic relationship between "Parafollicucullus" and "Pseudoalbaillella U-forma", and it may be that these forms belong to a shortlived (Leonardian-early Wordian) lineage separable from the main Pseudoalbaillella -- Follicucullus progression. Alternatively, Parafollicucullus may be seen as the immediate ancestor of Follicucullus, implying that the pseudothorax was lost in the transition and that the median, bilobate segment of Follicucullus is homologous with the non-bilobate Parafollicucullus abdomen.

(xxix) The "Pseudoalbaillella" ancestry of Follicucullus is strongly supported both by the fundamental similarities of the trisegmented shells and the development in some later "Pseudoalbaillellas" of the bilobed pseudothorax seen in Follicucullus. The internal rods demonstrated in the apical cone of Follicucullus are apparently vestigial columellae inherited from the Albaillella ancestor.

( $x x x$ ) "Mammilate spheroids". Superficially similar to Praeconocaryomma Rust, but not sufficiently well preserved for close comparison.

(xxxi) "Helioasters". Never satisfactorily seen, but apparently forms with thinly discoidal lattice, the disc margin ornamented wi th numerous spines. 
(xxxi i) "Simple multicyrtoids". Small, parallel-sided, multicyrtoid tests, lacking clearly differentiated cephalis, thorax or abdomen, with single pore girdle per post-cephalic segment. 


\section{SELECTED BIBLIOGRAPHY}

Foreman, H. P., 1963, Upper Devonian Radiolaria from the Huron member of the Ohio Shale: Micropaleontology, v. 9, p. 267-304.

Holdsworth, B. K., 1966, Radiolaria from the Namurian of Derbyshire:

Palaeontology, v. 9, p. 319-329.

1969, The relationship between the genus Albaillella Deflandre

and the ceratokisciid Radiolaria: Micropaleontology, v. 15, p. 230-236.

1973. The Radiolaria of the Baltalimani Formation, Lower Carboniferous, Is tanbul, in Kaya, 0., (ed.), Paleozoic of Istanbul: Ege Universitesi Fen Fakultesi Kitaplar Seresi, no. 40, p. 117-134. 1977, Paleozoic Radiolaria: stratigraphic distribution in Atlantic Borderlands, in Stratigraphic micropaleontology of Atlantic Basin and Borderlands: Amsterdam, Elsevier Publishing Co., p. 167-184. Holdsworth, B. K., Jones, D. L., and Allison, C., 1978, Upper Devonian radiolarians separated from chert of the Ford Lake Shale, Alaska: U.S. Geological Survey Journal of Research, v. 6, p. 775-788. Jones, D. L., Silberling, N. J., Csejtey, Bela, Nelson, W., and Blome, Charles, in press, Age and structural significance of the Chulitna ophiolite and adjoining rocks, south-central Alaska: U.S. Geological Survey Professional Paper 1121-A.

Nazarov, B. B., 1975, Radiolyarii nizhnego-srednego paleozoya kazakhstana [Lower and Middle Paleozoic Radiolaria of Kazakhstan]: Akademiya Nauk SSSR, Ordena Trudovogo Krasnogo znameni Geologicheskii Institut, Trudy, Vyp. 275, 202 p. (Published by Nauka, Moscow.) 
Nigrini, C., and Nitecki, M. H., 1968, Occurrence of Radiolaria in the Mississippian of Arkansas: Fieldiana, Geology, v. 16, p. 255268.

Nodine-Zeller, D., Holdsworth, B. K., and Berensen, P., in press, Well-preserved Middle and Late Pennsylvanian Radiolaria from Kansas, U.S.A.: International Carboniferous Congress, 9th, Compte Rendu, Urbana, Illinois, 1979.

Ormiston, A. R., and Babcock, L., 1979, Follicucullus, new radiolarian genus from the Guadalupian (Permian) Lamar Limestone of the Delaware Basin: Journal of Paleontology, v. 53, p. 328-334. Ormiston, A. R., and Lane, H. R., 1976, A unique radiolarian fauna from the Sycamore Limestone (Mississippian) and its biostratigraphic significance: Palaeontographica, Abteilung, v. 154, p. 158-180. Pessagno, E. A., Jr., and Newport, R. L., 1972, A technique for extracting Radiolaria from radiolarian cherts: Micropaleontology, v. 18, p. $231-234$

Smith, J. F., and Ketner, K. B., 1975, Stratigraphy of Paleozoic rocks in the Carlin Pinon Range area, Nevada: U.S. Geological Survey Professional Paper 867-A, 87 p.

Winder, C. G., 1966, Conodont zones and stratigraphic variability in Upper Devonian rocks, Ontario: Journal of Paleontology, v. 40, p. $1275-1293$. 
Table 1. Location of samples shown on plate 2.

Locality

USGS

ALASKA-CHULITNA

$\begin{array}{lll}78-J C h-12 & 0077 & \text { Jones } \\ 78-J C h-15 & 0078 & \text { Jones } \\ 76-J-1 & 0072 & \text { Jones } \\ 76-J-13 & 0074 & \text { Jones } \\ 76-J-26 & 0082 & \text { Jones } \\ 76-J-19 & 0080 & \text { Jones } \\ 76-J-20 & 0081 & \text { Jones } \\ 76-A W n-164 & 0070 & \text { Jones } \\ 76-A W n-162 & 0069 & \text { Jones } \\ 76-J-9 & 0073 & \text { Jones }\end{array}$

Healy A-6

Healy $A-6$

Healy A-6

Healy $A-6$

Healy A-6

Healy $A-6$

Healy A-6

Healy $A-6$

Healy A-6

Healy $A-6$

ALASKA-WRANGELLIA

$79-\mathrm{JMH}-11$
$79-\mathrm{JMH}-6$
$78-\mathrm{JCh}-30$
$79-\mathrm{JH}-3$
$79-\mathrm{JH}-1$
$79-\mathrm{JH}-2$

ALASKA-MCKINLEY

79-ARh-10B

79-ARh-10D

ALASKA-KANDIK BASIN

FORD LAKE SHALE

C-8

C-7

C -6

A-854

C -5

C -4

C-3

C-2

BC-75-127

Basal Nodules

$\begin{array}{ll}0784 & \text { Jones } \\ 0780 & \text { Jones } \\ 0435 & \text { Jones } \\ 0820 & \text { Jones } \\ 0818 & \text { Jones } \\ 0819 & \text { Jones }\end{array}$

0834

0836

Holdsworth

Collection

Holdsworth

Collection

Holdsworth

Collection

Holdsworth

Collection

Holdsworth

Collection

Holdsworth

Collection

Holdsworth

Collection

Holdsworth

Collection

Holdsworth

Collection
Richter

Richter

Talkeetna $A-6$

Talkeetna A-6
Mt. Hayes A-1

Mt. Hayes A-1

Healy $A-1$

Healy A-1

Healy $A-1$

Healy A-1
Holdsworth Yukon River, Ford Lake Shale, Eagle D-1

Holdsworth Yukon River, Ford Lake Shale, Eagle D-1

Holdsworth Yukon River, Ford Lake Shale, Eagle D-1

Holdsworth Yukon River, Ford Lake Shale, Eagle D-1

Holdsworth Yukon River, Ford Lake Shale, Eagle $D-1$

Holdsworth Yukon River, Ford Lake Shale, Eagle D-1

Holdsworth Yukon River, Ford Lake Shale, Eagle D-1

Holdsworth Yukon River, ford Lake Shale, Eagle D-1

Holdsworth Yukon River, Ford Lake Shale, Eagle D-1 
USGS

MR Number Collector Quadrangle
Locality

ALASKA-INNOKO

$68 \mathrm{a}-\mathrm{VABM}-$ Moose

71-Ch-89

77-APa-8

77-APa-6c

77-APa-7C

$77-\mathrm{Ch}-17$

75-APa-120

77-APa-183A

77-APa-73

$75-\mathrm{APa}-118$

$77-\mathrm{APa}-75$

77-APa-75B

$77-\mathrm{Ch}-18$

$77-\mathrm{Ch}-16$

ALASKA-70-MILE

77-AFr-3189

ALASKA-MYSTIC

79-JT-1

79-JT-15

79-JT-16

$79-\mathrm{JT}-13$

79-JT-2

79-JT-3

79-JT-12

79-JT-14

$79-\mathrm{JT}-15$

79-JT-4

79-JT-5

79-JT-6

79-JT-7

79-JT-8, 8a

$79-\mathrm{JT}-18$

$\begin{array}{lll}0954 & \text { Chapman } & \text { Tanana } \\ 0955 & \text { Chapman } & \text { Tanana } \\ 0096 & \text { Patton } & \text { Medfra } \\ 0956 & \text { Patton } & \text { Medfra } \\ 0957 & \text { Patton } & \text { Medfra } \\ 0055 & \text { Chapman } & \text { Ruby } \\ 0095 & \text { Patton } & \text { Medfra } \\ 0109 & \text { Patton } & \text { Medfra } \\ 0100 & \text { Patton } & \text { Medfra } \\ 0093 & \text { Patton } & \text { Medfra } \\ 0101 & \text { Patton } & \text { Medfra } \\ 0101 B & \text { Patton } & \text { Medfra } \\ 0056 & \text { Chapman } & \text { Ruby } \\ 0054 & \text { Chapman } & \text { Ruby }\end{array}$

0349

Foster/Keith Big Delta D-1

$\begin{array}{lll}0762 & \text { Jones } & \text { Talkeetna A-6 } \\ 0774 & \text { Jones } & \text { Talkeetna A-6 } \\ 0075 & \text { Jones } & \text { Talkeetna A-6 } \\ 0772 & \text { Jones } & \text { Talkeetna A-6 } \\ 0763 & \text { Jones } & \text { Talkeetna A-6 } \\ 0764 & \text { Jones } & \text { Talkeetna A-6 } \\ 0771 & \text { Jones } & \text { Talkeetna A-6 } \\ 0773 & \text { Jones } & \text { Talkeetna A-6 } \\ 0774 & \text { Jones } & \text { Talkeetna A-6 } \\ 0765 & \text { Jones } & \text { Talkeetna A-6 } \\ 0766 & \text { Jones } & \text { Talkeetna A-6 } \\ 0767 & \text { Jones } & \text { Talkeetna A-6 } \\ 0776 & \text { Jones } & \text { Talkeetna A-6 } \\ 0769,0768 & \text { Jones } & \text { Talkeetna A-6 } \\ 0777 & \text { Jones } & \text { Talkeetna A-6 }\end{array}$

ALASKA-BROOKS RANGE

$\begin{array}{ll}78-A C n-892 & 0804 \\ 78-M d-37 & 0798 \\ 78-E K-55 B & 0386 \\ 78-E K-19 C & 0816 \\ 78-E K-62 & 0817 \\ 75-A T r-50.5 & 0809 \\ 78-A C n-714 & 0805 \\ 78-A C n-713 & 0806 \\ 78-A C n-732 & 0807\end{array}$

Churkin

Mayfield Misheguk Mountain

Ellersieck Misheguk Mountain

Ellersieck Misheguk Mountain

Ellersieck Misheguk Mountain

Tailleur Killik River

Churkin

Churkin

Churkin
Misheguk Mountain

Misheguk Mountain

Misheguk Mountain 
USGS

Locality

MR Number

Collector

Quadrangle

ALASKA-BROOKS Range--cont.

$\begin{array}{ll}78-A C n-644 & 0808 \\ 77-A C n-723 & 0022 \\ 77-A C n-725 & 0023 \\ 77-A C n-1012 & 0025 \\ 78-M d-950 & 0042 \\ 77-M d-140 & 0039 \\ 77-M d-85 B & 0045 \\ 78-A V y-282 & 0416 \\ 78-A T r-58 B & 0810 \\ 77-A C n-1172 & 0027 \\ 78-A C n-721 & 0812 \\ 78-M d-75 E & 0813 \\ 75-A T r-50.2 .1 & 0811 \\ 78-M d-29 E & 0367 \\ 60-A B e-588 & 0002 \\ 77-A C n-371 & 0012 \\ 77-A C n-373 & 0013 \\ 78-A C n-203 & 0814 \\ 78-A C n-894 & 0815 \\ 78-M d-80 C & 0372 \\ 78-M d-80 D & 0373 \\ 77-M d-84 & 0044 \\ 77-M d-82 X & 0374 \\ 78-A C n-204 & 0960 \\ 78-A C n-1122 & 0802 \\ 60-A B e-591 D & 0004 \\ 78-M d-101 C & 0800 \\ 78-M d-81 C & 0801 \\ 78-E k-50 e .2 & 0380 \\ 60-A R r-663 & 0112 \\ 60-A B e-589 & 0003 \\ 77-A H e-56 & 0035 \\ M P-41 & 0953 \\ 78-A C n-201 & 0803 \\ & \end{array}$

Churkin

Churkin

Churkin

Churkin

Mayfield

Mayfield

Mayfield

Vickery

Tailleur

Churkin

Churkin

Mayfield

Tailleur

Mayfield

Brosge

Churkin

Churkin

Churkin

Churkin

Mayfield

Mayfield

Mayfield

Mayfield

Churkin

Churkin

Brosge

Mayfield

Mayfield

El lersieck

Reiser

Brosge

Churkin

Payne

Churkin

Travers

Monger

Holdsworth
Misheguk Mountain Misheguk Mountain Misheguk Mountain Howard Pass

Misheguk Mountain Misheguk Mountain Misheguk Mountain Misheguk Mountain Misheguk Mountain Howard Pass

Misheguk Mountain Misheguk Mountain Killik River

Misheguk Mountain Arctic

Misheguk Mountain Misheguk Mountain Howard Pass

Chandler Lake

Misheguk Mountain Misheguk Mountain Misheguk Mountain Misheguk Mountain Howard Pass Howard Pass Arctic

Misheguk Mountain Misheguk Mountain Misheguk Mountain Christian Arctic Howard Pass Arctic Howard Pass

BRITISH COLUMBIA-CACHE CREEK

Trav-059
MV-76-4A
$78-B K H-1 D b$
0245

0237

Holdsworth Collection
Cache Creek O'Donnel River Cache Creek 
USGS

Locality

MR Number Collector Quadrangle

WASHINGTON-SAN JUAN ISLANDS \& NORTH CASCADES

$\begin{array}{lll}\text { Wh-77-55H } & 0136 \mathrm{H} & \text { Whetten } \\ \text { Wh;78;34 } & 0499 & \text { Whetten } \\ \text { Wh-77-55F } & 0136 \mathrm{~F} & \text { Whetten } \\ \text { Wh-77-55B } & 0136 \mathrm{~B} & \text { Whetten } \\ \text { Wh-5E } & 0120 \mathrm{E} & \text { Whetten }\end{array}$

Roche Harbor 7 $\frac{1}{2}$ Roche Harbor 7 $\frac{1}{2}$ Roche Harbor $7 \frac{1}{2}$, Roche Harbor 7 $\frac{1}{2}{ }^{\prime}$ Arlington East 7 $\frac{1}{2}$

NEVADA-HAVALLAH SEQUENCE

$\begin{array}{lll}\text { 77-JNev-12 } & 0196 & \text { Jones } \\ \text { 77-JNev-19 } & 0203 & \text { Jones } \\ \text { 77-JNev-24 } & 0208 & \text { Jones } \\ \text { 77-JNev-16 } & 0200 & \text { Jones } \\ \text { 78-Sp-100 } & 0555 & \text { Speed } \\ \text { SNy-77-P1 } & 0615 & \text { Snyder } \\ \text { SNy-77-T16 } & 0624 & \text { Snyder } \\ \text { SNy-77-P3 } & 0617 & \text { Snyder } \\ \text { SNy-77-P2 } & 0616 & \text { Snyder } \\ \text { SNy-77-F8 } & 0613 & \text { Snyder } \\ \text { SNy-77-EM5 } & 0611 & \text { Snyder } \\ \text { SNy-77-T27 } & 0625 & \text { Snyder }\end{array}$

Antler Peak $2^{\circ}$ China Mountain $2^{\circ}$ China Mountain $2^{\circ}$ China Mountain $2^{\circ}$ Mt. Tobin Leach Hot Springs 15' Leach Hot Springs $15^{\prime}$ China Mountain 7 $7 \frac{1}{2}$ China Mountain $7 \frac{1}{2}$ ' Mount Moses Edna Mountain $1^{\prime}$ Buffalo Springs 15'

NEVADA-TOIYABE RANGE (PABLO)

Spd-106A

Spd-Pablo 290

77-FP-31F

NEVADA-QUINN RIVER

79-JNev-3

79-JNev-4

79-JNev-5

79-JNev-6

0607

0608

0742

Speed

Speed

Poole

Jones

Jones

Jones

Jones

NEVADA-MINA

78-JNev-9

$79-S p-S-10$

$79-S p-5-8$

OREGON

WR-9A

GC $-4 A$
0693

0958

0686

0689

0690

0848

0847

0959
Jones

Speed

Speed

Blome

Blome
Tonopah Ranger Dist. D-5 Tonopah Ranger Dist. D-5 Pablo Canyon $7 \frac{1}{2}{ }^{\prime}$

Quinn River Crossing 15' Quinn River Crossing 15' Quinn River Crossing 15' Quinn River Crossing 15'

Camp Douglas 7 $\frac{1}{2}$

Walker Lake $2^{\circ}$

Walker Lake $2^{\circ}$

Supplee area

Supplee area 